\title{
Supervisi Pengajaran Kepala Sekolah Berbasis Kearifan Lokal dalam Meningkatkan Profesional Guru (Studi Multi Situs pada SMAN 1 Kota Bima, SMAN 1 Bolo Kab. Bima dan SMAN 1 Dompu Kab. Dompu Provinsi NTB)
}

\section{Ruslan}

SMAN 1 Soromandi

ruslansmansa65@gmail.com

\section{Artikel Info}

Tanggal Publikasi

2019-12-30

\section{Kata Kunci}

Supervisi Pengajaran

Kearifan Lokal

Kepala Sekolah

Profesionalisme

\begin{abstract}
Abstrak
Pembinaan terhadap guru adalah bagian dari pengembangan pedagogik, kepribadian, profesional dan sosial. Penelitian ini dirancang dengan pendekatan kualitatif dengan rancangan penelitian yang digunakan adalah studi multi situs dengan seting penelitian dilakukan pada tiga sekolah yaitu SMA Negeri 1 Kota Bima, SMA Negeri 1 Bolo Kab. Bima, dan SMAN 1 Dompu dengan informan kunci yaitu Kepala Sekolah, dan informan lainnya adalah Pengawas Pendidikan Dikmen Diknas kab./kota, seluruh wakil kepala sekolah, beberapa guru, kepala staf tata usaha, dan siswa. Berdasarkan paparan data, temuan penelitian, pembahasan serta disajikan kesimpulan sebagai berikut: 1) proses supervisi dilakukan dengan menggunakan teknik-teknik supervisi seperti: kunjungan kelas, inservice education and training, rapat guru/pegawai, teamteaching, serta pendekatan klinis dan artistik. 2) Tanggapan guru terhadap pelaksanaan supervisi; (a) pembinaan yang tepat oleh kepala sekolah menumbuhkan komitmen serta motivasi guru untuk melakukan yang terbaik, dan (b) kesadaran mereka akan pentingnya supervisi yang berlandaskan pada nilai-nilai kearifan lokal. 3) Kendala, kesulitan yang dihadapi dalam pelaksanaan supervisi, yaitu (a) beban mengajar; (b) keterbatasan waktu kepala sekolah maupun guru; (c) dana, perannya sangat mendukung sekali dalam pelaksanaan supervisi pengajaran; (d) komitmen, dan (e) perasaan senioritas. 4) Peningkatan profesionalisme guru ditandai dengan: (a) kompetensi guru meningkat dalam perbaikan situasi pembelajaran, (b) kinerja guru meningkat dalam disiplin tugas, perencanaan pembelajaran dan menumbuhkan prakarsa dan jiwa pengabdian yang tinggi dan terlihat dari perilaku dan bahasa kepala sekolah dan guru yang berlandaskan nilai-nilai kearifan lokal dari motto daerah Bima/Dompu (ededu ndai sura dou labo dana, maja labo dahu dan nggahi rawi pahu) melalui keteladanan, kedisiplinan, ketekunan, ketelitian.
\end{abstract}

\section{Pendahuluan}

Menyadari bahwa pendidikan sebagai proses budaya untuk meningkatkan harkat dan martabat manusia, memiliki banyak aspek, salah satu aspek esensial yaitu belajar keterampilan dasar (learning of basic skills) sebagai kemampuan minimal yang harus dimiliki oleh setiap peserta didik, agar dapat mengembangkan diri (Sonhadji, 2012;97). Oleh karena itu, struktur kurikulum yang ditetapkan berdasarkan UU Sistim Pendidikan Nasional Nomor 20 Tahun 2003 dalam pasal 36 tentang kurikulum menyebutkan (1) pengembangan kurikulum dilakukan dengan mengacu pada standar nasional pendidikan untuk mewujudkan tujuan pendidikan nasional; (2) kurikulum pada semua jenjang dan jenis pendidikan dikembangkan dengan prinsip diversifikasi sesuai dengan satuan pendidikan, potensi daerah, dan peserta didik; (3) kurikulum disusun sesuai dengan jenjang pendidikan dalam kerangka Negara Kesatuan Republik Indonesia dengan memperhatikan: a) peningkatan iman dan taqwa; b) peningkatan ahlak mulia; c) peningkatan potensi, kecerdasan, dan minat peserta didik; d) keragaman potensi daerah dan lingkungan; e) tuntutan pembangunan daerah dan nasional; f) tuntutan dunia kerja; g) perkembangan ilmu pengetahuan, teknologi, dan seni; h) agama; i) dinamika pekembangan global; dan j) persatuan nasional dan nilai-nilai kebangsaan. 
Adapun proses budaya untuk meningkatkan harkat dan martabat manusiadalam pelaksanaan supervisi pengajaran yaitu dengan memasukkan nilai-nilai kearifan lokal ke dalam semua tindakan dan ucapan yang dilakukan kepala sekolah untuk melaksanakan supervisi pengajaran baik pada saat observasi di kelas serta melalui pendekatan klinis dan artistik. Hal tersebut dilakukan dengan tujuan untuk memperbaiki performan guru dalam mengajar dan untuk menanamkan nilai-nilai kearifan lokal pada guru dan siswa melalui kedisiplinan dan keteladanan.

Supervisi pengajaran merupakan suatu proses, yaitu serangkaian kegiatan pengawasan untuk membantu guru meningkatkan kemampuan profesionalnya. Supervisi pengajaran oleh kepala sekolah berbasis kearifan lokal yang bersumber dari motto daerah kab./kota Bima-Dompu sebagaimana supervisi pada umumnya adalah merupakan proses berkesinambungan yang menekankan penanaman nilai-nilai kearifan lokal dengan tahapan-tahapan kegiatan-kegiatan dengan menggunakan pendekatan supervisi klinis untuk mencapai tujuan yang telah ditetapkan, sebagai berikut: 1) persiapan dan memberitahukan guru yang akan disupervisi; serta teknik-teknik supervisi kelompok, seperti rapat dewan guru dan Musyawarah Guru Mata Pelajaran (MGMP).2) pengamatan guru yang mengajar didampingi guru sejenis, dalam menyukseskan proses belajar mengajar dan bermuara pada kualitas peserta didik, dan dalam menanamkan nilai-nilai kearifan lokal yang terkandung dalam motto daerah" Ededu Ndai Sura Dou Labo Dana, maja labo dahu dan nggahi rawi pahu"; dan 3) pertemuan balikan mendiskusikan tentang perbaikan pengajaran yang merupakan temuan dan disesuaikan dengan administrasi yang dibuat guru (nggahi rawi pahu).

Dalam pertemuan awal dengan guru yang akan disupervisi, kepala sekolah selalu menanamkan nilai menghargai kelebihan orang lain sehingga menimbulkan keinginan yang kuat untuk belajar banyak dari orang yang ditiru dalam hal ini kepala sekolah dan begitu juga sebaliknya, kepala sekolah menghargai guru dengan menganggap guru sebagai kolega bukan sebagai bawahan. Sehingga guru tidak merasa diinstropeksi, serta merangsang guru untuk berusaha sedapat mungkin melakukan yang terbaik sesuai yang direncanakan dalam program kerja guru (administrasi kurikulum). Hal ini sesuai dengan nilai yang terkandung dalam motto daerah"Nggahi Rawi Pahu" dan malu tidak bisa melakukan yang terbaik buat anak didik "Maja Labo Dahu dan Edesi Ndai Sura Dana Labo Dou", karena Allah SWT Tuhan YME mengajar manusia untuk memiliki sifat rendah diri dan berahlak mulia.

Suhardan (2010), dalam era otonomi daerah, supervisi pengajaran di sekolah berfungsi untuk: a) jaminan kualitas, di mana Pemda/Pemkot memenuhi kewajiban pendidikan terhadap masyarakatnya, memperlihatkan keseriusan dalam mengurus daerahnya; b) pendorong mutu sekolah, di mana banyak teknik-teknik supervisi yang dapat dijalankan untuk meningkatkan mutu sekolah; c) transparansi pembelajaran bagi anak dan orang tua, transparansi dalam belajar berarti kemudahan peserta didik dalam menerima pelajaran dari gurunya, dan bagi orang tua dalam memantau atau mengikuti perkembangan belajar anaknya.; d) indikator sekolah di daerah telah berjalan efektif; dan e) supervisi pendidikan di era otonomi daerah harus dapat dijadikan sebagai alat untuk menjamin mutu pendidikan (quality assurance in education), sebab di era otonomi daerah pelayanan publik berkualitas menjadi konsep kebijakan yang harus dilaksanakan dengan penuh rasa tanggung jawab.

Dalam rangka melaksanakan konsep pendidikan yang mengacu pada pendidikan nilai di era otonomi daerah, Pemerintah Daerah/Pemerintah Kota menginstruksikan jajaran Dinas Pendidikan Pemuda dan Olahraga (Dikpora) untuk kembali pada pendidikan yang berbasis kearifan lokal, karena disadari bahwa pendidikan tersebut yang mengakarkan dirinya pada konteks sekolah, akan mampu menjiwai dan mengarahkan sekolah pada penghayatan pendidikan karakter yang realistis, konsisten, integral. Paling tidak ada lima unsur yang bisa dipertimbangkan, yaitu: a) mengajarkan, b) keteladanan, c) menentukan prioritas, d) praksis prioritas, e) refleksi, Suhardan (2010;212). Sesuai dengan pendapat Dantley (2003:16-17) menyatakan bahwa dalam melakukan pengembangan sekolah (termasuk guruguru) perlu memasukkan unsur spiritual, terutama untuk sekolah-sekolah atau guru-guru di 
daerah.Adapun proses penilaian (assesment) yang dicapai dalam proses supervisi adalah bagian integral dari proses pembelajaran dan terintegrasi dalam keseluruhan proses supervisi sehingga berdampak pada perbaikan dan peningkatan mengajar guru serta peningkatan kualitas siswa pada tiga situs penelitian tersebut (Rebert \& Kaeli, 2002).

Hasil orientasi lapangan menggambarkan bahwa salah satu upaya yang ditempuh oleh ketiga kepala sekolah SMAN situs penelitian untuk memperbaiki pengajaran guru dan menanamkan nilainilai kearifan lokal adalah melaksanakan supervisi pengajarn berbasis kearifan lokal secara efektif. Hasil wawancara menggambarkan bahwa kepala SMAN situs penelitian mengedepankan supervisi pengajaran berbasis kearifan lokal dalam meningkakan profesionalisme guru. Adapun langkah-langkah yang juga ditempuh dalam melaksanakan supervisi pengajaran berbasis kearifan lokal adalah: a) mendengarkan (kade'e) pemaparan guru dalam rangka menghargai kelebihan dan kekurangan guru dalam rangka saling asah, asih, asuh (ededu ndai sura dou labo dana) b) mengklarifikasi permasalahan yang ditemui selama observasi kelas (ngoara tei pemecahan masalah), c) mendorong memecahkan masalah (mbei semangat) dengan tujuan agar mampu melakukan terbaik (maja labo dahu) d) memberikan contoh keteladanan, e) menentukan prioritas (nggahi rawi pahu), e) refleksi

Implementasi muatan kearifan lokal dalam pelaksanaan supervisi terintegrasi dalam tingkah laku serta bahasa kepala sekolah sebagai supervisor, yang lebih tahu tentang keadaan sekolah secara keseluruhan, termasuk personil pendidik dan tenaga kependidikan yang berada di sekolah. Tentunya kearifan lokal yang dimaksud di sini bersumber dari tiga motto daerah kota/kabupaten 1) "Ededu Ndai Sura Dou Labo Dana" (mengutamakan kepentingan masyarakat umum daripada diri dan kelompok),terimplementasi dalam sikap dan tingkah laku kepala sekolah/guru yang mendahulukan kepentingan masyarakat (stakeholder) melalui siswa yang diajar dan dididik daripada kepentingan diri dan keluarga. 2)"Maja Labo Dahu" (malu dan takut sama Allah SWT dan sesama manusia), terimplementasi dalam tingkah laku kepala sekolah/guru dalam melakukan perbaikan proses pembelajaran yang berasaskan malu kalautidak bisa mengajar dan mendidik siswa karena sudah menjadi tanggung jawab dunia akhirat. 3) Nggahi Rawi Pahu (apa yang diucapkan harus bisa direalisasikan), terimplementasi dalam sikap dan tingkah laku kepala sekolah/guru yang dengan tanggung jawab yang besar dalam memberikan yang terbaik apa yang telah dipahami atau yang telah direncanakan dalam proses pembelajaran kepada siswa.

\section{METODE}

Penelitian ini menfokuskan pada supervisi pengajaran berbasis kearifan lokal yang dilakukan oleh kepala sekolah sebagai supervisor pada tiga sekolah menengah atas di Kabupaten/Kota Bima, yaitu SMAN 1 Kota Bima; SMAN 1 Bolo dan SMAN 1 Dompu .

Berdasarkan karakteristik subyek dan fokus penelitian tersebut, penelitian ini dirancang dengan menggunakan pendekatan kualititatif dengan rancangan studi multi situs. Dalam penelitian ini pada awalnya akan menggunakan metode yang pertama yaitu dengan metode induksi analitis termodifikasi (modified analytic induction) dengan beberapa alasan, yaitu (1) data yang akan dikumpulkan hanya berkisar pada masalah pelaksanaan supervisi, faktor pendukung dan penghalang pelaksanaan supervisi berbasis kearifan lokal dalam meningkatkan profesionalisme guru; dan (2) ketiga SMAN tersebut memiliki prestasi yang baik di Kota Bima, Kabupaten Bima, dan Kabupaten Dompu, yang ditengarai oleh berpengaruhnya pelaksanaan supervisi berbasis kearifan lokal oleh kepala sekolah.

\section{HASIL DAN PEMBAHASAN}

\section{Hasil}

Pelaksanaan supervisi pengajaran kepala sekolah berbasis kearifan lokal: (1) Kunjungan kelas: (a) mempersiapkan program supervisi dilakukan pada awal tahun ajaran baru melalui rapat dewan guru 
(kasabua nggahi/persepsi tentang tujuan supervisi); (b) menginformasikan guru yang akan disupervisi dan waktu observasi (ngoa ra tei guru); (c) melaksanakan supervisi di kelas bersama guru sejenis yang senior (lu'u tio guru ma tei); (d) mendiskusikan hasil observasi kelas dan umpan balik (feedback) dengan guru yang diobservasi bersama guru sejenis yang ikut serta dalam pelaksanaan supervisi; (2) In service education and training: (a) studi lanjut ke jenjang lebih tinggi baik S1 maupun S2 melalui seleksi yang dilakukan BKD sesuai dengan kebutuhan karena masalah anggaran; (b) peningkatan kompetensi melalui, komputer; (c) MGMP, semiloka tingkat sekolah maupun kabupaten atau penyertaan pada kegiatan seminar \& pelatihan di luar daerah; (3) Rapat rutin guru/pegawai: (a) merencanakan rapat rutin baik tahunan, bulanan maupun mingguan untuk mengevaluasi program-program ysng telah berhasil dan belum tuntas yang diikuti komite sekolah \& pengawas dikpora: (b) merumuskan tujuan rapat (kasabua nggahi atas dasar nggahi rawi pahu) guru/pegawai sebagai bagian dari kewajiban bagi semua komponen sekolah (ededu ndai sura dou labo dana); (4) Team-teaching: (a) peningkatkan keahlian dalam kelompok guru sejenis atau serumpun terutama pada mata pelajaran yang memiliki lebih dari 2 kredit untuk menjembatani perbedaan persepsi guru sejenis dalam merealisasikan kbm yang telah diprogramkan (nggahi rawi pahu) serta menyatukan persepsi tentang metode mengajar; (b) peningkatan rasa tanggung jawab dan kepedulian terhadap rekan sejawat dan peningkatan rasa saling membutuhkan sesama guru sehingga tidak merasa lebih tahu dari yang lain; (5) Supervisi klinis: (a) Pemberian supervisi ini biasanya difokuskan pada perbaikan pembelajaran pada guru yang mengalami hambatan dalam proses belajar mengajar meliputi perencanaan, pengamatan, analisis pada penampilan; (6) Supervisi artistik: (a) pembinaan melalui supervisi ini ditujukan untuk penanaman nilai-nilai keagamaan \& kearifan lokal; (b) pembinaan setiap upacara bendera hari Senin; (c) pembacaan Yasin bersama hari Jum'at, (maja labo dahu) pada Allah SWT/Tuhan YME; (d) pembentukan seksi kerohanian OSIS; (e) silaturrahim sebelum jam pertama dimulai; (f) Keberhasilan pelaksanaan supervisi pengajaran kepala sekolah berbasis kearifan lokal sangat tergantung pada keteladanan, kedisiplinan, ketelitian, serta ketelatenan dalam mengapresiasi nilai-nilai yang terkandung dalam motto daerah; (7) Semua kegiatan dalam proses supervisi dilandasi oleh motto daerah Bima/Dompu (ededu ndai sura dou labo dana, maja labo dahu, dan nggahi rawi pahu)

Tanggapan guru terhadap supervisi pengajaran kepala sekolah berbasis kearifan lokal: (1) Guru merasa banyak terbantu dalam memperbaiki situasi pembelajaran; (2) Pembinaan yang tepat telah membangkitkan semangat belajar, mempertinggi kegairahan dan kesungguhan dalam mengajar, mempertinggi kreativitas dan motivasi berprestasi, dan mempertinggi rasa tanggung jawab terhadap tugas; (3) Supervisi pengajaran yang baik dan menyenangkan dapat menumbuhkan serta membangkitkan semangat dan gairah kerja guru, menumbuhkan komitmen terhadap tugas; (4) serta dapat mempertinggi etos kerja dan kejujuran, memperkuat loyalitas dan disiplin; (5) Komitmen serta motivasi guru adalah kunci dalam melakukan yang terbaik untuk perbaikan situasi pembelajaran dan menanamkan nilai-nilai kearifan lokal dengan berlandaskan pada motto daerah kab./kota BimaDompu; (6) Kesadaran tinggi akan pentingnya supervisi karena dilandasi oleh pemahaman akan nilainilai luhur dalam motto daerah Kab./Kota Bima-Dompu "ededu ndai sura dou labo dana , maja labo dahu dan nggahi rawi pahu".

Kendala yang dihadapi dalam Pelaksanaan Supervisi Pengajaran Berbasis Kearifan Lokal: (1) Beban mengajar: (a) $24 \mathrm{JP} /$ minggu (sertifikasi guru) dan memenuhi dengan kegiatan lain seperti teamteaching bagi guru yang tidak terpenuhi (maja labo dahu \& nggahi rawi pahu); (b) mencari solusi terbaik agar guru mampu memperbaiki pengajaran walaupun dengan jumlah jamnya 24 JP; (c) beban mengajar tidak dirasakan guru karena kesadaran mereka pada peran gandanya baik sebagi pengajar maupun pendidik; (2) Keterbatasan waktu: (a) melimpahkan tugas supervisi kepada wakasek atau guru senior dilandasi oleh kepercayaan kepala sekolah akan kemampuan guru-guru; (b) kesadaran guru pada siapapun yang melakukan supervisi (konsisten); (c) melimpahkan tugas pemeriksaan administrasi kurikulum dilimpahkan pada wakasek kurikulum; (3) Pendanaan: (a) Kepala sekolah bersama komite 
sekolah mencarikan solousinya melalui APBS atau dana lain yang memungkinkan seperti anggaran BOS (Bantuan Operasional Sekolah); dan (b) Kebersamaan kepala sekolah dengan komite sekolah dilandasi oleh nilai-nilai luhur dalam motto daerah Kab./Kota Bima-Dompu; (4) Komitmen dan tanggung jawab: komitmen dan tanggungjawab kepsek/guru pada tugas karena dilandasi oleh pemahaman mereka pada tugas dan kewajiban serta pemahaman akan nilai-nilai luhur dalam motto daerah Kab./Kota Bima-Dompu; (5) Tingkat kompetensi guru yang beragam: komitmen dan tanggungjawab pada tugas bisa teratasi karena dilandasi oleh pemahaman kepsek/guru pada tugas dan kewajiban serta nilai-nilai luhur dalam motto daerah Kab./Kota Bima-Dompu; (6) Senioritas: (a)membantu rekan guru dengan tidak merasa menggurui dan digurui terutama pada guru-guru baru dan guru yang membutuhkan; (b) budaya sekolah dengan memberikan pengakuan terhadap prestasi kerja dengan tetap memperhatikan senioritas guru \& dalam mengkomunika-sikan harapan tinggi pada pencapaian belajar \& nilai moral siswa (maja labo dahu, nggahi rawi pahu); (c) Kebersamaan serta kesadaran akan kelebihan dan kekurangan diri guru akan bisa memecahkan kendala dalam pelaksanaan supervisi pengajaran berbasis pada nilai-nilai kearifan lokal pada ketiga motto " ededu ndai sura dou labo dana, maja labo dahu dan nggahi rawi pahu".

Peningkatan Profesionalisme Guru Sebagai Pengaruh Supervisi Pengajaran Berbasis Kearifan Lokal: (1) Kompetensi guru meningkat dalam perbaikan situasi pembelajaran melalui semua kegiatan supervisi pengajaran kepala sekolah berbasis kearifan lokal; (2) Kinerja guru meningkat dalam disiplin tugas, di antaranya mematuhi peraturan yang telah dibuat bersama, menyelesaikan tugas yang diberikan kepala sekolah, loyalitas dan etos kerja meingkat, serta bijak dan santun dalam bertindak; (3) Mampu menumbuhkan dan membangkitkan inisiatif, prakarsa, kemauan bekerja dengan jiwa pengabdian yang tinggi (ededu ndai sura dou labo dana); (4) Profesionalisme guru sebagai hasil dari keteladanan, kedisiplinan, ketekunan, ketelitian, ketepatan guru yang tetap berlandaskan pada nilai-nilai luhur yang terkandung dalam motto daerah Kab./Kota Bima-Dompu (ededu ndai sura dou labo dana, maja labo dahu, nggahi rawi pahu).

\section{Pembahasan}

1) Proses Supervisi Pengajaran Berbasis Kearifan Lokal

Pelaksanaan supervisi pengajaran berdasarkan pada kemampuan berkomunikasi yang sopan, santun, halus yang merupakan cerminan dari makna yang terkandung dalam motto daerah kota/kab.Bima-Dompu (ededu ndai sura dou labo dana, maja labo dahu, nggahi rawi pahu), serta kemampuan mendengarkan keluhan, masukkan dan pertanyaan guru-guru dalam rangka perbaikan performan mengajar mereka.

Pelaksanaan supervisi kunjungan kelas dilakukan oleh kepala sekolah tidak hanya pada tataran perbaikan situasi pembelajaran saja akan tetapi juga pada masalah penanaman nilai-nilai kearifan lokal yang berlandaskan pada motto daerah tersebut melalui keteladanan, kedisiplinan, ketelitian, ketekunan, dan ketepatan yang dicontohkan oleh kepala sekolah dan guru. Kegiatan kunjungan kelas diawali dengan: 1) memberitahukan guru yang akan disupervisi (ngoara tei guru), di mana kepala sekolah berperilaku dan menggunakan bahasa yang santun sehingga guru yang akan disupervisi merasa diperhatikan akan perbaikan pengajaran dan tidak merasa dimata-matai ;2) observasi kelas (lu'u tio guru ma tei), memperhatikan penampilan guru dalam mengajar apa sudah sesuai rencana program pembelajaran (RPP) yang telah diprogramkan dan dimulai dari proses belajar mengajar sampai dengan menutup pelajaran sesuai dengan makna dari motto daerah (mengutamakan keberhasilan dalam proses belajar mengajar (nggahi rawi pahu; 3) menyimpulkan hasil observasi dan umpan balik (feedback) (ngoara tei sawa'u lu'u dei kelas), dilakukan dalam mengoreksi kelebihan yang sudah dilakukan dalam proses belajar mengajar untuk dipertahankan atau ditingkatkan dan kekurangannya untuk segera diperbaiki. Kegiatan tersebut didasari oleh kemauan bersama kepala 
sekolah dan guru untuk memperbaiki baik performan mengajar guru maupun perilaku kepala sekolah dalam proaes supervisi yang pantas diteladani (digugu dan ditiru).

Teknik supervisi in service education and training dimaksudkan untuk meningkatkan kemampuan guru-guru baik melalui kegiatan MGMP, semiar, dan semiloka, dan melanjutkan studi pada jenjang lebih tinggi. Semua kegiatan tersebut diatas dilandasi oleh tanggung jawab yang tinggi sekolah terhadap peningkatan kualitas siswa melalui peningkatan kualitas pembelajaran oleh guru yang berkualitas pula, sehingga mendahulukan kepentingan siswa dan guru di atas segalanya, mampu merealisaskin semua program peningkatan kualitas di sekolah yang dilandasi oleh rasa takut dan malu kalau tidak mampu melakukan yang terbaik untuk peningkatan kualitas siswa.

Adapun pelaksanaan rapat rutin guru/karyawan dilakukan sekali sebulan, serta rapat mingguan yang dilakukan setelah pelaksanaan upacara bendera hari senin. Hal tersebut dimaksudkan memperoleh masukkan serta perbaikan terhadap program yang telah dilaksanakan, dengan 1) merumuskan tujuan rapat yang berkaitan dengan peningkatan kualitas pembelajaran, dilakukan setiap minggu dan setiap awal bulan; 2) mencarikan solusi terhadap permasalahan yang ditemukan. Semua kegiatan tersebut dilandasi oleh rasa tanggung jawab terhadap tugas, sehingga dengan kebersamaan antara semua komponen di sekolah diharapkan akan mempermudah mencarikan solusi yang terbaik untuk kebersamaan juga (kepedulian pada masalah individu guru sebagai masalah bersama selama berkaitan dengan kemajuan pendidikan di sekolah).

Kebersamaan adalah situasi yang selalu ditanamkan pada semua komponen sekolah pada tiga situs penelitian demi peningkatan mutu pendidikan di sekolah. Kegiatan team-teaching bertujuan untuk: 1) meningkatkan keahlian guru dalam mengajar dengan saling asih-asah-asuh sesama guru sejenis maupun serumpun (kasih ade sesama guru) sesuai dengan nilai "ededu ndai sura dou labo dana" agar guru saling mengisi satu sama lainnya; 2) meningkatkan kepedulian terhadap sesama guru dalam meningkatkan profesionalisme guru dalam mengajar, sehingga tidak menciptakan situasi menggurui dan digurui (ngoara tei sesama guru); dan 3) meningkatkan rasa tanggung jawab bersama (karawi sama guru labo iyu weki wati loa), didasari oleh perasaan takut tidak mampu berbuat terbaik untuk siswa (maja labo dahu).

Pendekatan supervisi artistik yang merupakan suatu pendekatan yang menyandarkan pada kepekaan, persepsi, dan pengetahuan supervisor sebagai sarana untuk mengapresiasi kejadian-kejadian pengajaran yang bersifat halus, lembut dan mengedepankan ahlak mulia dalam berperilaku seperti ramah, santun, jujur, toleran, bijak, ketulusan hati yang sangat bermakna di dalam kelas. Pendekatan ini sangat memperatikan hubungan baik dan menyenangkan antara supervisor dan guru yang disupervisi sehingga tercipta suasana dialogis dan akrab di antara mereka. Kegiatan-kegiatan yang dilakukan oleh kepala sekolah dalam pendekatan artistik adalah sebagai berikut: a) pembinaan setiap upacara bendera hari senin (ngoara tei di guru/siswa), b) pembacaan Yasinan bersama setiap hari Jum'at, c) pembentukan seksi kerohaniaan OSIS, dan d) Kegiatan menyalami sesama guru dan siswa (jabatanga sesamaguru labo siswa).

Dalam era otonomi daerah, sekolah sebagai lembaga pelaksanaan kegiatan pada tingkat pelayanan pendidikan yang paling depan (operasional) memiliki banyak keuntungan, seperti pengambilan keputusan yang lebih berbasis pada persoalan sendiri. Sehingga realisasinya lebih efektif dan efisien, lebih bertanggung jawab dalam semua masalah pengelolaan kegiatan sekolah, tumbuhnya kepercayaan pada kemampuan sendiri, melakukan kerjasama dengan lembaga lain yang dibutuhkan dalam upaya memajukan sekolah. Salah satu cara pengelolaan kegiatan sekolah yaitu dengan melaksanakan supervisi pengajaran yang berbasis kearifan lokal. Supervisi pengajaran dimaknai sebagai bantuan kepada guru atau berfungsi sebagai pengembangan profesional guru (Ruscinski \& Hazi, 2007).

Konsep human capitaldi era otonomi daerah ini, berhubungan dengan kenyataan bahwa manusia berinvestasi dalam dirinya sendiri melalui pendidikan, di mana pemerintah daerah 
memiliki komitmen pada peningkatan mutu sumber daya manusia yang akan senantiasa mempedulikan upaya-upaya peningkatan mutu pendidikan dalam usaha meraih kepercayaan masyarakat (Dadang, 2010). Selain hal tersebut, keuntungan yang dapat diraih dari kebijakan desentralisasi adalah (1) lebih mendekatkan pengambilan keputusan dengan masyarakat yang menjadi sasarannya sehingga operasionalisasi keputusan dapat lebih realistis, efektif, dan efisien; (2) meringankan beban organisasi pada level yang lebih tinggi sehingga dapat menggunakan waktu, energi dan perhatiannya ke sasaran yang lebih strategik; (3) membina kemampuan bertanggung jawab pada tingkat yang lebih rendah; dan (4) menumbuhkan kebanggaan para pelaksanaan pada tingkat yang lebih rendah karena merasa dipercaya oleh pemerintah yang lebih tinggi dalam mengambil keputusan.

Melalui tiga (3) proses analisis kebijakan yang berupa: 1) perumusan masalah; 2) evaluasi; dan 3) rekomendasi, diharapkan kebijakan yang telah dibuat dapat dipertanggungjawabkan karena merupakan produk bersama semua komponen yang ada di sekolah, termasuk pelaksanaan supervisi pengajaran berbasis kearifan lokal dalam meningkatkan profesionalisme guru dan menanamkan nilai-nilai luhur budaya daerah yang berlandaskan motto daerah kab/kota Bima-Dompu pada ketiga situs penelitian. Hal tersebut juga diungkapkan Banun (2008) menjelaskan tentang keefektivan pelaksanaan supervisi diperlukan satu program yang membuat berbagai aktivitas atau kegiatankegiatan yang akan dikerjakan oleh supervisor dalam melaksanakan supervisi, kegiatan yang dimaksudkan dalam penelitian ini yaitu peningakatan profesionalisme guru dan penanaman nilainilai kearifan lokal melalui supervisi pengajaran.

Sesuai yang diungkap Sukmadinata (2006), bahwa iklim, budaya dan perubahan memiliki hubungan dalam kegiatan supervisi pendidikan di sekolah, di mana asumsinya bahwa iklim dan budaya sekolah merupakan dua faktor psikologi dan simbolik dari sekolah yang terlebih dahulu perlu dikondisikan secara baik agar perubahan yang diinginkan dalam kegiatan supervisi dapat tercapai. Senada dengan Bolman \& Deal (2002) bahwa konsep budaya membantu kita untuk menguji kembali sekolah sebagai tempat dari komunitas manusia yang memiliki sejarah dan cerita khusus. Tentunya hal tersebut sangat sesuai dengan pelaksanaan supervisi pengajaran berbasis kearifan lokal yang dilakukan oleh kepala sekolah, membutuhkan keteladan, kedsiplinan oleh kepala sekolah pada semua komponen yang ada di sekolah dengan latar belakang motto daerah kab./kota yang berbeda dan bisa dipakai bersama pada tiga daerah kab./kota, di samping memiliki budaya dan bahasa yang sama, ternyata mampu meningkatkan profesionalisme guru yang berdampak pada peningkatan kualitas siswa yang berlandaskan pada nilai-nilai kearifan lokal . Pengembangan profesional melalui supervisi pengajaran berbasis kearifan lokal yang berkelanjutan dan intensif akan memberikan dampak yang lebih baik daripada dengan jangka waktu pendek atau sesaat (Garet, Porter, Desimori dan Birman, 2001).

Dalam pelaksanaan supervisi pengajaran berbasis kearifan lokal pada tiga SMA Negeri yaitu dengan model supervisinya disesuaikan dengan kondisi masing-masing sekolah, guru-gurunya. Permasalahan yang dihadapi serta kompetensi yang dimiliki guru diidentifikan pada awal pembelajaran sehingga memudahkan model pembinaan yang ditawarkan kepada guru (Zepeda, 2012;41). Kepala sekolah menyadari bahwa pembinaan melalui supervisi pengajaran akan berhasil dengan baik jika ada dukungan dari para guru yang ada di sekolah tersebut. Untuk dapat melaksanakan pembinaan semacam itu, kepala sekolah harus memiliki kemampuan interpersonal dalam hubungan manusiawi (Caminiti, 2005).

Keputusan kepala sekolah pada tiga SMAN latar penelitian untuk menitikberatkan pada pelaksanaan supervisi kunjungan kelas, supervisi klinis, dan supervisi artistik merupakan kebijakan yang didasarkan pada potensi dan kondisi yang ada pada tiga sekolah tersebut. Kondisi yang dimaksud di sini adalah masih banyak guru-guru baru yang kurang berpengalaman dan memiliki 
potensi untuk berkembang serta ketersediaan waktu yang dimiliki oleh supervisor dalam memperbaiki performan mengajar guru di samping menekankan pada aspek penguasaan materi serta cara penyampaiannya tetapi juga pada penanaman nilai-nilai kearifan lokal yang terkandung dalam ketiga motto daerah Kab/Kota Bima, yaitu "maja labo dahu, ededu ndai sura dana labo dou dan nggahi rawi pahu" . Supervisi kunjungan kelas biasanya dilakukan dalam tiga bagian, yaitu: (a) persiapan administrasi dan penguasaan materi; (b) proses supervisi; dan (c) pertemuan balikan. Supervisi klinis yang dilakukan pada tiga SMAN latar penelitian pada prinsipnya dilaksanakan bersama dengan tiga kegiatan pokok, yaitu: (1) pertemuan pendahuluan (pre-conference) (ngoara tei sawati lu'u observasi), (2) observasi mengajar, dan (3) pertemuan balikan (post-conference) (ngoara tei swa'u lu'u observasi).

Sebagaimana Muhtar \& Iskandar (2009), bahwa istilah klinis di sini menunjuk kepada unsurunsur khusus sebagai berikut: (1) adanya hubungan tatap muka antara supervisor dan guru di dalam proses supervisi, (2) fokus pada tingkah laku yang sebenarnya dari guru di dalam kelas, (3) observasi secara cermat, (4) pendeskripsian data observasi secara terperinci, (5) supervisor dan guru secara bersama-sama menilai penampilan guru, dan (6) fokus observasi sesuai dengan kebutuhan dan penampilan guru.

Di samping itu, walaupun proses supervisi tidak lagi bermakna mengontrol tetapi memberdayakan guru dalam upaya memperbaiki performan mengajar, akan tetapi proses kontrol tetap dijadikan pedoman dalam pelaksanaan, yaitu berupa: a) mengukur performan yang nyata dari guru, b) membandingkan hasil dengan standar yang telah ditetapkan sebelumnya, c) serta melakukan perbaikan (Robbins\& DeCenzo, 2004).

Menurut Pondy, Liwin (2001) pembelajaran budaya melalui pelaksanaan supervisi pengajaran berbasis kearifan lokal berarti mempelajari bagaimana kejadian-kejadian dan interaksi-interaksi antara komponen-komponen sekolah menghasilkan makna, budaya di sini yang berlatar belakang kearifan lokal yang berbasis pada motto ketiga daerah Kab./Kota "maja labo dahu, ededu ndai sura dana labo dou dan nggahi rawi pahu" sebagai serangkaian pemahaman atau pengertian yang diberikan oleh kelompok masyarakat tersebut, dalam hal ini masyarakat pendidikan pada tiga situs penelitian. Orientasi nilai-nilai yang terkandung dalam ketiga motto daerah Kab./Kota, dipercayai dan dianut oleh kelompok masyarakat Bima/Dompu dalam kehidupan mereka sehari-hari (Kartodihardjo, 2002).

Lebih lanjut kepala sekolah memberikan apresiasi pada guru yang berkualitas, dengan cara menjaring dari siswa untuk menilai guru-guru yang bagus melayani proses kegiatan belajar mengajar di kelas pada setiap semester. Apresiasi bisa berupa sertifikat guru teladan tingkat sekolah untuk diusulkan ke tingkat kab/kota. Hal ini sejalan dengan apa yang menjadi budaya sekolah yang juga merupakan bagian dari nilai-nilai kearifan lokal ketiga daerah Kab./Kota. Menurut John Saphier dan Mattiuw King (2002), tentang appreciation and recognition, dimana supervisor yang baik adalah yang bisa memberikan pengakuan dan penghargaan atas prestasi guru yang dicapainya. Guru yang berprestasi dalam mengajar adalah guru yang akan mendapat pengakuan dan penghormatan dari murid-muridnya.

2) Tanggapan guru terhadap supervisi pengajaran kepala sekolah berbasis kearifan lokal

Komitmen serta motivasi guru adalah kunci dalam melakukan yang terbaik untuk perbaikan situasi pembelajaran dengan berlandaskan pada penanaman nilai-nilai kearifan lokal yang terkandung dalam motto daerah kab./kota Bima-Dompu " ededu ndai sura dou labo dana, maja labo dahu, dan nggahi rawi pahu”.Pembinaan yang tepat telah membangkitkan semangat belajar, mempertinggi kegairahan dan kesungguhan dalam mengajar, mempertinggi kreativitas dan motivasi berprestasi, dan mempertinggi rasa tanggung jawab terhadap tugas.Supervisi pengajaran dapat 
mempertinggi etos kerja dan kejujuran, memperkuat loyalitas dan disiplin. Kesadaran tinggi akan pentingnya supervisi karena dilandasi oleh pemahaman akan nilai-nilai luhur dalam motto daerah Kab./Kota Bima-Dompu. Disini perlunya kemampuan kepala sekolah dalam memahami guru-guru yang menanggapi salah pada program supervisi yang dilakukan dengan cara mengobservasi anggota guru, memahami mereka, berkomunikasi dengan mereka, membuat aturan berperilaku yang harus diikuti pada masa akan datang, dan menghilangkan perilaku yang tidak baik.

Walaupun pada awalnya masih ada guru menganggap perlakuan supervisi pengajaran terutama yang dilakukan melalui kunjungan kelas sebagai suatu pemantauan atau penginspeksian atau tindakan memata-matai untuk mencari kesalahan guru. Hal ini disebabkan oleh beberapa hal sebagai berikut: (a) supervisi disamakan dengan evaluasi, (b) supervisi dilakukan untuk menjalankan tugas bukan karena atas dasar kebutuhan, (c) supervisi dilakukan secara tradisional, dan (d) supervisor kurang menguasai tugas-tugas dan teknik-teknik supervisi, sehingga cenderung monoton, dan tidak sistematis, kadang bersifat sangat subyektif dan tidak terukur.

Guru-guru yang berada pada tiga SMAN latar penelitian kebanyakan sudah menyadari akan kewajiban kepala sekolah sebagai supervisor melakukan supervisi pengajaran di lembaga yang dipimpinnya. Tanggapan guru-guru tersebut sangat positif, tentunya kepala sekolah juga harus menindaklanjutinya dengan melakukan kunjungan kelas.Model supervisi pengajaran yang diterapkan oleh kepala sekolah (1) memberikan rasa kenyamanan dan menghargai potensi guru, (2) menghadirkan suasana keterbukaan dan kekeluargaan di antara para guru, (3) lebih efektif dan efisien dalam meningkatkan profesionalisme guru, dan (4) menjadikan guru merasa bebas dalam mengembangkan potensi diri. Sesuai yang diungkap Sergiovanni dalam Bafadal (1994) bahwa supervisi pembelajaran sebagai serangkaian kegiatan membantu guru untuk mengembangkan kemampuannya mengelola proses pembelajaran demi pencapaian tujuan pembelajaran.

Senada dengan ini, menurut Alton, Frish, dan neville, bahwa ada tiga konsep pokok dalam pengertian supervisi pembelajaran, yaitu: (1) supervisi pembelajaran harus secara langsung mempengaruhi dan mengembangkan perilaku guru dalam proses pembelajaran, (2) perilaku supervisor dalam membantu guru mengembangkan kemampuannya harus didesain secara ofisial, jelas kapan mulai dan kapan mengakhiri program pengembangan tersebut, dan (3) tujuan akhir supervisi pembelajaran adalah agar guru semakin mampu memfasilitasi proses pembelajaran bagi para siswanya. Lebih lanjut.

Di samping itu demi lancarnya pelaksanaan supervisi kepala sekolah berbasis kearifan lokal juga dipengaruhi oleh lima dimensi kepercayaan (Schindler \& C.C Thomas, 2003), yaitu: a) integritas (kejujuran dan sifat yang sebenarnya), b) kompetensi(pengetahuan keahlian secara teknis dan intepersonal), c) konsistensi (dapat dipercaya, dapat diprediksi dan keputusan yang baik dalam mengatur situasi), d) loyalitas (keinginan untuk melindungi dan menjaga), dan e) keterbukaan (keinginan untuk membagi ide dan informasi dengan bebas). Dengan demikian rasa kepercayaan yang dimiliki guru dan diperlihatkan oleh kepala sekolah juga sangat berpengaruh terhadap sikap penerimaan dari guru yang menjadi subyek supervisi yang dilakukan oleh kepala sekolah, terlebih dalam meningkatkan peran serta masyarakat pendidikan dalam menghargai dan mengimplementasikan nilai-nilai kearifan lokal di sekolah khusus dan di masyarakat pada umumnya. Mantja (2008) mengemukakan bahwa perilaku seseorang ditentukan oleh persepsinya. Sebaliknya persepsi seseorang terhadap obyek atau lingkungannya ditentukan oleh kebutuhankebutuhannya. Sikap menjadi alasan persepsinya.Selanjutnya dikatakan bahwa hubungan sikap dan perilaku adalah hubungan kausalitas. Karena itu, sikap seseorang menentukan apa yang akan dikerjakannya.

Disamping itu juga motivasi merupakan bagian penting dalam setiap kegiatan, tanpa motivasi tidak ada kegiatan yang nyata. Callahan dan Clark (dalam Mulyasa, 2004) mengemukakan bahwa 
"motivasi adalah tenaga pendorong atau penarik yang menyebabkan adanya tingkah laku ke arah tujuan tertentu." Persepsi dan motivasi guru terhadap pelaksanaan superviasi pengajaran berbasis kearifan lokal oleh kasek pada tiga situs penelitian, umumnya positif. Karena dengan supervisi pengajaran, dapat: 1) membantu guru untuk memperbaiki dan meningkatkan proses pembelajaran dalam meningkatkan mutu pendidikan dengan berlandaskan pada nilai-nilai kearifan lokal; 2) membantu guru dalam mengembangkan kompetensinya, yaitu kompetensi pedagogik, kompetensi prosfesional, kompetensi sosial, dan kompetensi kepribadian; 3)membantu guru untuk mengetahui kekurangan atau kelemahan yang dimilikinya dan bagaimana memperbaikinya.Jadi, dengan memiliki motivasi untuk juga menanamkan nilai-nilai kearifan lokal di samping motivasi guru menjadi professional menjadikan supervise pengajaran berbasis kearifan lokal semakin bermakna.

3) Kendala yang dihadapi dalam pelaksanaan supervisi pengajaran berbasis kearifan lokal

Keterbatasan waktu yang dimiliki kepala sekolah maupun guru bisa dicarikan solusi, apalagi keterbatasan waktu karena ada tugas dinas yang merupakan bagian dari tugas kepala sekolah maupun guru. Di situlah kesadaran semua pihak baik guru maupun sekolah, yang terpenting adalah bagiamanapun cara harus ditempuh agar siswa tidak menjadi pihak yang dikorbankan. Sikap kepala sekolah maupun guru dalam mendahulukan kepentingan anak didik di atas segalanya, dan malu untuk tidak memberi terbaik buat anak-anak hanya karena urusan pribadi atau keluarga. Hal tersebut sangat sesuai dengan nilai-nilai luhur yang terkandung dalam motto "maja labo dahu dan ededu ndai sura dou labo dana".

Kebersamaan kepala sekolah dengan komite dalam melakukan apa saja agar masalah pendanaan yang juga merupakan kendala tidak menjadi penyebab mundurnya mutu pendidikan di sekolah. Melalui anggaran pendapatan belanja sekolah (APBS) dari masyarakat dan anggaran lain yang memungkinkan akan dipakai demi peningkatan mutu pendidikan serta kesejahteraan semua komponen sekolah. Hal tersebut sangat sesuai dengan makna nilai-nilai yang terkandung dalam motto "nggahi rawi pahu, dan ededu ndai sura dou labo dana".

Tingkat komitmen, kebersamaan dan tanggung jawab guru-guru yang tinggi pada program yang dibuat dan disepakai bersama juga merupakan kunci keberhasilan guru dalam meningkatkan profesionalisme dan dalam memahamai dan menjalankan nilai-nilai luhur yang terkandung dalam motto daerah kab./kota Bima-Dompu. Tingkat komitmen serta tanggung jawab yang tinggi yang dimiliki guru-guru yang menandai senioritas mereka dalam berperilaku, bukan hanya karena faktor usia. Terpenting bagaimana mampu melakukan yang terbaik demi kemajuan anak didik itulah yang selalu menjadi pedoman bagi mereka untuk di gugu dan ditiru. Hal tersebut sangat sesuai dengan makna nilai-nilai luhur dari motto "nggahi rawi pahu dan maja labo dahu" (berperilaku sebagai seorang yang senior yang ditiru oleh yunior mereka dan malu dengan istilah senioritas tapi nggak mampu melakukan yang terbaik untuk kemajuan pendidikan di sekolah). Dengan menyadari kekurangan dan kelebihan dimiliki menimbulkan toleransi guru untuk saling mengisi di antara mereka, tidak merasa menggurui dan digurui. Semua sikap yang diperlihatkan oleh guru-guru pada ketiga SMAN situs penelitian sangat sesuai dengan makna nilai-nilai yang terkandung dalam motto daerah Kab./Kota Bima-Dompu.

Pelaksanaan supervisi pengajaran pada tiga SMAN sebagai latar penelitian bukan tanpa kendala. Di antara kendala-kendala yang ditemukan dalam penelitian ini adalah sebagai berikut: (a) sistem pembinaannya yang kurang memadai, karena kepala sekolah lebih banyak memfokuskan pada pembinaan administrasi daripada profesionalismenya guru. Dalam hal ini kesadaran guru akan tanggung jawab untuk peserta didik serta keingintahuan mereka akan perkembangan ilmu pengetahuan mampu menjadi solusi terbaik; (b) kurangnya tatap muka antara kepala sekolah dengan semua guru dalam supervisi pengajaran di kelas. Solusi yang diambil oleh kepala sekolah adalah dengan melibatkan atau mewakilkan pelaksanaan supervisi pengajaran kepada wakasek, atau guru 
senior pada masing-masing bidang studi untuk membantu melakukan supervisi pengajaran pada rekan sejawatnya; (c) sikap mental yang kurang menunjang, dimana hubungan profesional yang kadang-kadang kaku dan kurang akrab antara atasan dan bawahan, sehingga guru nggak mau terbuka pada kepala sekolah sebagai atasannya; dan (d) kurang terkoordinasinya kegiatan pembinaan yang dilakukan kepala sekolah sebagai supervisor (Mantja, 2002).

Penentuan model supervisi pengajaran yang diberikan pada masing-masing guru tidak harus sama, karena keberagaman guru-guru pada tiga SMAN latar penelitian tersebut. Faktor-faktor yang dijadikan bahan pertimbangan dalam menentukan model supervisi pengajaran yang dianggap tepat adalah (1) keberagaman kompetensi dan karakter guru, (2) potensi yang dimiliki oleh sebagian guru yang berbeda satu sama lainnya, (3) kepadatan kegiatan kepala sekolah, dan (4) kebutuhan profesional guru. Gordon (2001) menekankan pada dua cara mendasar untuk menilai tingkat perkembangan, keahlian, dan komitmen guru, semuanya akan dipertimbangkan pada saat memilih pendekatan supervisi yang digunakan. Cara yang lain yaitu mendiskusikan dengan guru tentang siswa, pengajaran dan perbaikan pengajaran.

Kendala yang berkaitan dengan beban mengajar guru muncul pada pelaksanaan program inservice tarining and education, yaitu pada saat guru (1) mendapatkan kesempatan untuk melanjutkan studi ke jenjang yang lebih tinggi, (2) harus menyisihkan waktu untuk mengikuti kegiatan semiloka yang diadakan oleh MGMP kabupaten, propinsi, (3) harus mengikuti pelatihan atau menjadi nara sumber pada pelatihan tertentu di kecamatan maupun di kabupaten/kota. Kendala yang berkaitan dengan beban mengajar guru yang cukup padat bisa menjadi masalah klasik yang memang tidak mudah diatasi, terlebih dengan mewajibkan guru yang sudah disertifikasi mengajar 24 jam pelajaran dengan jumlah guru PNS yang banyak. Permasalahan jam mengajar bagi guru yang telah disertifikasi bisa dicarikan solusinya setelah kepala sekolah membicarakan permasalahan tersebut pada saat rapat musyawarah kerja kepala sekolah (MKKS) di Dikpora kabupaten/kota bersama Kepala Dinas dan para pengawas.

Efektivitas sekolah terdiri dari dimensi manajemen dan kepemimpinan sekolah, guru, tenaga kependidikan, personel lainnya, siswa, kurikulum, sarana prasarana, pengelolaan kelas, hubungan sekolah dan masyarakatnya, pengelolaan bidang khusus lainnya, hasil nyatanya merujuk pada hasil yang diharapakan bahkan menunjukkan kedekatan atau kemiripan antara hasil nyata dengan hasil yang diharapkan.(Kartika, 2009).

Lebih lanjut Saiful (2004), supervisi dan evaluasi pelaksanaan tugas mengajar dilaksanakan untuk menjawab dua pertanyaan mendasar, yaitu pada batasan mana sebaiknya guru mengimplementasikan dan melaksanakan model pengajaran dan bagaimana siswa mencapai hasil belajar. Inti permasalahan dalam mewujudkan sekolah efektif bahwa guru harus mampu mengembangkan kemampuan mengajarnya, dan siswa harus mendapat pelayanan yang terbaik dalam mencapai hasil belajar, jadi tidak dikenal adanya kekosongan jam belajar di kelas.

Kendala lain dalam pelaksanaan program in-service education and training adalah masalah waktu pelaksanaan yang diharapkan akan dapat secara efektif dan efisien memberikan hasil yang maksimal bagi peningkatan profesionalisme guru dan untuk menanamkan nilai-nilai kearifan lokal pada peserta training.Tahapan-tahapan dalam in-service education selalu diperlihatkan contoh keteladanan serta kedisiplinan guru-guru yang mengandung makna-makna nilai kearifan lokal dalam bidang studi atau masalah yang diangkat dalam kegiatan tersebut. Semenjak pelatihan tersebut ada, telah membawa perubahan dalam peningkatan profesionalisme guru, juga harus memperhatikan setelah keluar dari program itu sendiri dalam mengimplementasikan hasil program.

4) Profesionalisme guru sebagai dampak dari pelaksanaan supervisi pengajaran berbasis kearifan lokal 
Profesionalisme guru ditandai dengan meningkat kompetensi guru dalam perbaikan situasi pembelajaran melalui semua kegiatan supervisi pengajaran kepala sekolah berbasis kearifan lokal. Kinerja guru meningkat dalam perencanaan pembelajaran, yang meliputi penyusunan tujuan pembelajaran, penyusunan bahan/materi pembelajaran, penetapan metode pembelajaran, penggunaan media pembelajaran dan dalam penyusunan instrument evaluasi.Kinerja guru meningkat dalam disiplin tugas, di antaranya mematuhi peraturan yang telah dibuat bersama, menyelesaikan tugas yang diberikan kepala sekolah, loyalitas dan etos kerja meingkat, serta bijak dan santun dalam bertindak.Mampu menumbuhkan dan membangkitkan inisiatif, prakarsa, kemauan bekerja dengan jiwa pengabdian yang tinggi.

Peningkatan kualitas guru harus senantiasa dilaksanakan untuk menyesuaikan dirinya dengan perkembangan dan perubahan zaman.Oleh karena itu, supaya profesionalisasi harus terus diperhatikan oleh guru dalam rangka menuju profesi yang sebenarnya.Sesuai yang diungkap (Ballantine, 2003), bahwa profesional adalah pribadi yang berkarakter dan memiliki kompetensikompetensi komponen intelektual seperti komitmen yang kuat terhadap karir yang didasari dari kemampuan bertanggung jawab sesuai dengan tugasnya dan kemampuan berorientasi terhadap pelayanan pelanggan. Lebih lanjut (Hendry L. Tosi, 2000) mengatakan bahwa orientasi profesional adalah kecakapan hidup yang menjadi sentral tugasnya dan bukan organisasinya, sehingga mereka mempunyai kecenderungan untuk melihat permintaan organisasi sebagai penekanan atau gangguan, dan mereka akan mencari jalan untuk menghindarinya.

Supervisi pengajaran merupakan bagian yang tak terpisahkan dari kegiatan peningkatan mutu dalam proses belajar mengajar di sekolah. Supervisi adalah suatu bentuk staff development di sekolah yang diharapkan akan mendatangkan manfaat bagi guru sendiri, yaitu untuk: (a) memperbaharui ketrampilan dan pengetahuan, (b) memantau dalam rangka memenuhi tuntutan perkembangan zaman, (c) mengetahui hasil-hasil riset dan perkembangan metode pengajaran dan pembelajaran, dan (d) mengetahui serta mengikuti perkembangan materi dan media pembelajaran. Program supervisi pengajaran yang dilaksanakan diharapkan secara efektif dan efisien menghasilkan guru yang (a) ahli di bidangnya, (b) bertanggung jawab terhadap profesinya, dan (c) memiliki kepedulian yang tinggi pada sejawatnya.

Ciri guru profesional yang dikemukakan oleh Sahertian (2002), yaitu bahwa seorang guru dikatakan profesional apabila dia (1) ahli dalam bidang ilmu pengetahuan yang digelutinya dan ahli dalam tugas mendidik, (2) memiliki otonomi atau kemandirian dalam mengemukakan apa yang harus dikatakan berdasarkan keahliannya, dan rasa tanggung jawab terhadap apa yang telah dia kemukakan dan lakukan dalam konteks keahliannya tersebut, dan (3) memiliki rasa kesejawatan yang ditandai dengan terpupuknya rasa peduli terhadap rekan sejawatnya, karena dia sadar bahwa kebiasaan semacam itulah merupakan cara untuk membentuk citra tertentu terhadap profesinya, yaitu dengan bekerja sama dengan sejawatnya. Ciri semacam itu muncul tentunya tidak terlepas dari bagaimana sebuah pekerjaan dapat dikatakan sebagai profesi.

Model supervisi pengajaran yang ditetapkan di SMAN 1 Kota Bima, SMAN 1 Bolo dan SMA Negeri 1 Dompu terdiri dari beberapa kegiatan supervisi pengajaran, yaitu (1) kunjungan kelas, (2) inservice education and training, (3) rapat rutin guru/karyawan, (4) penempatan guru dalam team teaching, (5) supervisi klinis, dan (6) supervisi artistik.

Kegiatan-kegiatan tersebut telah memberikan kontribusi yang besar dalam peningkatan profesionalisme guru yang ditandai dengan adanya peningkatan keahlian dari guru-guru pada tiga SMAN tersebut. Peningkatan keahlian tersebut dapat dilihat dari: (1) semakin bervariasinya teknik mengajar guru di kelas, (2) adanya kegiatan-kegiatan pembelajaran yang inovatif dan semakin kreatif, (3) pemberian tugas-tugas yang dapat menambah wawasan siswa tentang penerapan ilmu yang diajarkan dalam kehidupan nyata, (4) kepercayaan yang diberikan pada beberapa guru untuk 
menjadi nara sumber dalam kegiatan pelatihan yang dilakukan oleh kabupaten, misalnya dalam forum MGMP dan workshop Bintek kurikulum tingkat satuan pendidikan (KTSP) kota/kabupaten.

Dalam hal ini, Robin \& DeCenzo, (2004) menyatakan bahwa alasan utama dari tidak efektifnya sebuah kegiatan pelatihan adalah karena (1) guru kurang atau tidak mendapat dukungan untuk mengimplementasikan pengetahuan yang diperolehnya dari pelatihan, (2) kurang terorganisirnya kegiatan pelatihan yang diadakan, (3) kurangnya pemantauan selama guru mengimplentasikan hasil pelatihan tersebut, dan (4) kurangnya komitmen dari guru untuk mencoba apa yang telah dipelajarinya. Kepala sekolah pada tiga SMAN tersebut memberikan dukungan penuh pada guru-guru mengikuti kegiatan-kegiatan pelatihan yang meningkatkan profesionalisme mereka serta melakukan pemantauan pada saat mereka mengaplikasikannya dalam kegiatan belajar mengajar di kelas, sehingga meningkatkan keahlian pada diri mereka sesuai dengan bidang yang ditekuninya.

Selain peningkatan profesionalisme dalam bentuk peningkatan keahlian, kegiatan in-service education and trainning juga menghasilkan bentuk kepedulian guru pada teman sejawatnya. Hal tersebut lambat laun akan menimbulkan kekuatan dalam kebersamaan dan pengembangan guru secara pribadi maupun dalam kelompok. Glickman, at all (2009, p.12), bahwa pelaksanaan supervisi mempunyai pengaruh yang efektif untuk pengembangan guru secara langsung baik pribadi maupun dalam kelompoknya, serta pengembangan profesionalisme, pengembangan kurikulum dan penelitian tindakan.

Sementara itu, pelaksanaan supervisi pengajaran melalui kegiatan rapat rutin guru/karyawan setiap hari sabtu dua kali sebulan di tiga SMAN tersebut, juga ternyata mampu meningkatkan profesionalisme guru dari sisi kepedulian kepada teman sejawat serta rasa tanggung jawab terhadap profesinya. Selain itu juga, guru merasa bertanggung jawab untuk mengetahui perkembangan informasi di sekolah mereka, karena sedikit banyak informasi tersebut akan memberikan kontribusi positif dalam pelaksanaan kegiatan pembelajaran di kelas. Pembudayaan hal-hal tersebut secara langsung akan berpengaruh pada komitmen guru-guru pada sekolahnya untuk selalu mendukung perkembangan yang terjadi.

Rapat guru di tiga SMAN tersebut ada kalanya dilakukan secara insidental dan secara berkala. Rapat insidental biasanya dilakukan pada saat ada hal-hal penting yang perlu sesegera mungkin dibicarakan bersama untuk mencarikan solusinya, misalnya ada kasus perkelahian anak di sekolah yang menyebabkan masyarakat luar terlibat. Dalam hal ini dibicarakan cara penanggulangan dengan mengedepankan nilai-nilai kearifan lokal yang lama dipegang teguh oleh masyarakat Bima/Dompu yaituededu ndai sura dou labo dana, maja labo dahu, dan nggahi rawi pahu.

Pidarta (2009.p.172) bahwa ciri-ciri supervisi melalui rapat guru adalah: (1) supervisi diberikan pada sejumlah guru; (2) tempat supervisi pada umumnya di ruang guru atau di ruang serbaguna di sekolah bersangkutan; (3) waktu mengadakan supervisi bisa secara berkala dan dapat juga secara insidental, atau kedua-duanya secara bergantian bergantung kepada kebutuhan; (4) supervisi dipimpin oleh kepala sekolah di sekolah itu dengan posisi sebagai supervisor; (5) proses supervisi sebagaian besar melalui diskusi, sesudah kepala sekolah menjelaskan dan memberikan informasi bertalian dengan materi yang akan dibahas; dan (6) proses supervisi diakhiri dengan simpulan yang disepakati bersama.

Peningkatan profesionalisme guru juga diupayakan melalui pelaksanaan team teaching dan pembentukan kelompok bidang studi. Pelaksanaan kedua kegiatan supervisi pengajaran ini menghasilkan tiga hal yang menunjukkan adanya peningkatan profesionalime guru. Ketiga hal tersebut adalah: (1) peningkatan keahlian; (2) peningkatan kepedulian terhadap rekan sejawat; dan (3) peningkatan rasa tanggung jawab terhadap profesinya. Dalam teknik supervisi pengajaran melalui 
team teaching semacam ini, sekelompok guru bidang studi berhadapan dengan supervisor, dalam hal ini supervisornya adalah kepala sekolah atau kepala sekolah meminta bantuan guru senior (semi supervisor).

Pidarta (2009) mengutarakan ciri-ciri supervisi melalui team teaching, sebagai berikut: (1) supervisi bersifat kelompok; (2) yang bertindak sebagai supervisor adalah kepala sekolah atau guru senior; (3) guru yang disupervisi pada umumnya sama, sebab hal-hal yang dibahas dalam proses supervisi adalah yang bertalian dengan spesialisasi mereka; (4) tempat melakukan supervisi bisa di luar ruang kelas; (5) waktu mengadakan bisa insidental, kalau ada kelompok guru yang membutuhkan mendadak maka supervisinya bisa dilakukan; (6) proses supervisi sebagian besar dalam bentuk diskusi multi arah, saling menyambung antara peserta baik yang disupervisi maupun yang mensupervisi; (7) supervisi diakhiri denga simpulan; dan (8) tindak lanjut diadakan kalau peserta membutuhkannya.

Proses kerja sama di antara guru untuk meningkatkan profesionalisme mereka, sejalan dengan apa yang didefinisikan Glatthorn dalam Sergiovanni (1993) tentang Cooperative Professional Development, yaitu suatu proses yang melibatkan guru dan sejawatnya dalam sebuah kerja sama untuk pertumbuhan dan perkembangan profesionalnya. Oleh karena itu, penempatan guru dalam team teaching ini banyak sekali membantu kepala sekolah dalam mengatasi kendala dalam perbaikan perofrman mengajar guru, yaitu dengan melibatkan guru-guru senior pada masing-masing bidang studi dalam mensupervisi teman sejawat yang yunior.

Keuntungan-keuntungan dari pelaksanaan supervisi kelompok semacam itu, seperti yang diungkap DeCenzo\& Robin (2004), a) mengekonomiskan waktu kepala sekolah untuk melakukan supervisi pada semua guru; b) memberikan suasana yang mendukung, di mana guru bisa saling mengisi dan menyadari akan kekurangan diri dan sejawatnya; c) guru bisa menerima refleksi, masukan dari sejawat; d) memberikan kesempatan pada supervisor (kepala sekolah) untuk mengetes emosional guru atau respon intuisi (tanpa dipelajari) pada materi yang disajikan dengan mengecek pada respon sejawat mereka; e) bisa memberikan pengalaman yang luas sehingga mereka bisa lebih mengenal teman sejawat; f) memberikan banyak kesempatan untuk menggunakan teknik-teknik supervisi; dan g) konteks supervisi bisa berpengaruh sebagai terapi bagi guru yang disupervisi.

\section{KESIMPULAN}

Berdasarkan analisis dan pembahasan hasil penelitian di atas, maka dapat disimpulkan sebagai berikut:

1. Proses supervisi pengajaran kepala sekolah berbasis kearifan lokal

Proses supervisi pengajaran yang dilakukan kepala sekolah adalah dengan melakukan: (1) kunjungan kelas (lu'u tio guru ma tei), di mana kepala sekolah berperilaku dan menggunakan bahasa yang santun sehingga guru yang akan disupervisi merasa diperhatikan akan perbaikan pengajaran dan tidak merasa dimata-matai, memperhatikan penampilan guru dalam mengajar apa sudah sesuai rencana program pembelajaran (RPP) yang telah diprogramkan dan mendiskusikan kelebihan yang sudah dilakukan dalam proses belajar mengajar untuk dipertahankan atau ditingkatkan dan kekurangannya untuk segera diperbaiki. 2) inservice education and training: dimaksudkan untuk meningkatkan kemampuan guru-guru baik melalui kegiatan MGMP, seminar, dan semiloka, untuk menambah kompetensi yang belum diketahui sesuai dengan perkembangan dan selalu bertanya halhal yang penting berkaitan dengan materi pembelajaran, hal tersebut sesuai dengan nilai maja labo dahu dan nggahi rawi pahu (menyadari akan kekurangan diri dan tidak malu belajar terus), (3) rapat rutin guru/pegawai, menyatukan persepsi (kasabua nggahi), yang membicarakan tentang peningkatan kualitas pembelajaran demi siswa dan mencarikan solusi terhadap permasalahan yang ditemukan. 
(4) team teaching (mengajar tim/tei kasama), bertujuan untuk: (a) meningkatkan keahlian guru dalam mengajar dengan saling asih-asah-asuh sesama guru sejenis maupun serumpun (kasih ade sesama guru); (b) meningkatkan kepedulian terhadap sesama guru dalam meningkatkan profesionalisme guru dalam mengajar, sehingga tidak menciptakan situasi menggurui dan digurui (ngoara tei sesama guru), dan (c) meningkatkan rasa tanggung jawab bersama (karawi sama labo iyu weki wati loa), (5) supervisi klinis, dimaksudkan untuk perbaikan pembelajaran, terutama bagi guru yang mengalami hambatan dalam kegiatan belajar mengajar, dan (6) supervisi artistik, yang merupakan suatu pendekatan yang menyandarkan pada kepekaan, persepsi, dan pengetahuan supervisor sebagai sarana untuk mengapresiasi kejadian-kejadian pengajaran yang bersifat halus, lembut dan sangat bermakna di dalam kelas.

Keberhasilan pelaksanaan supervisi pengajaran kepala sekolah berbasis kearifan lokal sangat tergantung pada kedisiplinan, ketekunan, ketelitian, serta ketelatenan dalam mengapresiasi nilainilai yang terkandung dalam motto ketiga daerah kab./kota Bima-Dompu yang berlandaskan pada kemampuan berkomunikasi, kemampuan interpersonal, ahlak mulia untuk bisa meningkatkan kemampuan dalam pembelajaran dan perbaikan situasi pembelajaran.

2. Tanggapan guru terhadap supervisi pengajaran kepala sekolah berbasis kearifan lokal.

Tanggapan guru beragam, yaitu : (a) guru banyak terbantu dalam memperbaiki situasi pembelajaran, (b) pembinaan yang tepat telah membangkitkan semangat belajar, mempertinggi kegairahan dan kesungguhan dalam mengajar, mempertinggi kreativitas dan motivasi berprestasi, dan mempertinggi rasa tanggung jawab terhadap tugas serta dapat mempertinggi etos kerja dan kejujuran, memperkuat loyalitas dan disiplin, (c) komitmen serta motivasi guru adalah kunci dalam melakukan yang terbaik untuk perbaikan situasi pembelajaran \& menanamkan nilai-nilai kearifan lokal, sehingga dengan menyadari kekurangan yang dimiliki, guru berupaya belajar terus dan merasakan malu nggak mampu melakukan yang terbaik bagi diri dan siswa (maja labo dahu) dan (d) kesadaran tinggi akan pentingnya supervisi karena dilandasi oleh pemahaman akan nilai-nilai luhur dalam moto (ededu ndai sura dou labo dana, maja labo dahu, nggahi rawi pahu).

Kegiatan yang dilakukan oleh kepala sekolah dalam melaksanakan supervisi pengajaran berbasis kearifan lokal, semata-mata hanya untuk melakukan perbaikan terhadap situasi pengajaran yang dilakukan guru-guru dan menanamkan nilai-nilai kearifan lokal dengan berlandaskan moto daerah. Dengan keteladanan, kedisiplinan, ketelitian, ketekunan, dan ketepatan yang dicontohkan oleh kepala sekolah dan guru, ternyata berpengaruh signifikan pada kualitas dan perilaku siswa . Jadi, menumbuhkan komitmen dalam melakukan perbaikan situasi pembelajaran yang berlandaskan pada kearifan lokal adalah kata kunci dalam pencapaian profesionalisme guru baik dalam meningkatkan mutu pembelajaran maupun dalam menanamkan nilai-nilai kearifan lokal.

3. Kendala-kendala yang terjadi dalam pelaksanaan supervisi pengajaran kepala sekolah berbasis kearifan lokal dan pemecahannya

Beban mengajar yang banyak seakan sirna oleh perasaan malu dan takut dan berupaya sedapat mungkin melaksanakan kewajiban mengajar 24 JP (maja labo dahu) baik di hadapan Tuhan YME (Allah SWT) maupun dihadapan sesama guru, serta mengikuti kegiatan pelatihan yang bisa menambah kompetensi mereka. Gaji yang diberikan bukan tanpa tujuan yang lebih utama yaitu bagaimana siswa berhasil dengan upaya yang dilakukan kepala sekolah dan guru (ededu ndai sura dou labo dana), disinilah kepentingan masyarakat yang diutamakan melalui siswa di atas segalanya.

Keterbatasan waktu yang dimiliki kepala sekolah maupun guru bisa dicarikan solusi, apalagi keterbatasan waktu karena ada tugas dinas yang merupakan bagian dari tugas kepala sekolah maupun guru. Terpenting adalah bagiamanapun cara harus ditempuh agar siswa tidak menjadi pihak yang dikorbankan. Sikap kepala sekolah maupun guru pada ketiga SMAN situs penelitian 
memperlihatkan sikap mendahulukan kepentingan anak didik di atas segalanya, dan malu untuk tidak memberi terbaik buat anak-anak hanya karena urusan pribadi atau keluarga. Hal tersebut sangat sesuai dengan nilai-nilai luhur yang terkandung dalam motto "maja labo dahu dan ededu ndai sura dou labo dana".

Kebersamaan kepala sekolah dengan komite dalam melakukan apa saja agar masalah pendanaan tidak menjadi penyebab mundurnya mutu pendidikan di sekolah. Melalui anggaran pendapatan belanja sekolah (APBS) dari masyarakat dan anggaran lain yang memungkinkan akan digunakan demi peningkatan mutu pendidikan serta kesejahteraan semua komponen sekolah. Hal tersebut sangat sesuai dengan makna nilai-nilai yang terkandung dalam motto "nggahi rawi pahu, dan ededu ndai sura dou labo dana".

Tingkat komitmen dan tanggung jawab yang tinggi serta rasa kebersamaan yang dimiliki guruguru yang menandai senioritas mereka dalam berperilaku baik tehadap guru-guru yunior, tanpa melihat faktor usia. Terpenting bagaimana mampu melakukan yang terbaik demi kemajuan anak didik itulah yang selalu menjadi pedoman bagi mereka untuk di gugu dan ditiru. Hal tersebut sangat sesuai dengan makna nilai-nilai luhur dari motto "nggahi rawi pahu dan maja labo dahu" (berperilaku sebagai seorang yang senior yang ditiru oleh yunior mereka dan malu dengan istilah senioritas tapi tidak mampu melakukan yang terbaik untuk kemajuan pendidikan di sekolah).

4. Peningkatan profesionalisme guru sebagai pengaruh dari supervisi pengajaran kepala sekolah berbasis kearifan lokal

Peningkatan profesionalisme guru ditandai oleh: (a) kompetensi guru meningkat dalam perbaikan situasi pembelajaran melalui semua kegiatan supervisi pengajaran kepala sekolah berbasis kearifan lokal, (b) kinerja guru meningkat dalam disiplin tugas dan perencanaan pembelajaran dan mampu menumbuhkan prakarsa dan jiwa pengabdian yang tinggi, dan (c) profesionalisme guru sebagai hasil dari kedisiplinan, ketekunan, ketelitian guru yang tetap berlandaskan pada nilai-nilai luhur yang terkandung dalam motto daerah Kab./Kota Bima-Dompu (maja labo dahu, ededu ndai sura dou labo dana, nggahi rawi pahu).

Peningkatan profesionalisme guru juga nampak pada: (1) terjadinya peningkatan kesadaran kepala sekolah dan guru dalam usaha meningkatkan mutu pembelajaran dengan cara mengaktifkan pengawasan profesional yang berbasis kearifan lokal; (2) pengawasan profesional berhasil mempengaruhi guru meningkatkan mutu pembelajaran sehingga melahirkan kepuasan mengajarbelajar, komitmen yang kuat dan daya kerja yang semakin efektif; dan (3) kegiatan pengawasan berasaskan supervisi pengajaran berbasis kearifan lokal yang terorganisir dengan baik, dikemas dalam suasana kepemimpinan yang demokratis, sehingga nilai-nilai kearifan lokal tertanam dengan baik pada semua komponen sekolah (kepala sekolah, guru, siswa serta komite sekolah).

\section{Daftar Pustaka}

Ballantine, H.J. 2003. The Sociology of Education. A Systematic Analysis. New Jersey: Prentice Hall, Inc.

Banun, S.M. 2008.Supervisi Pendidikan Meningkatkan Kualitas Profesionalisme Guru. Bandung: Alfabeta.

Bolman, I.G \& Deal, T.F. 2002. Leading with Soul and Spirit. School Administrator, 59(2) 21-26.

Caminiti, S. 2005. What Team Leaders Need to Knows?. Fortune (February 20,2005)pp. 93-100.

Dantley, M. E. 2003.Critical Spiritually; Enhancing Transformative Leadership through Critical Theory and African American Prophetic Spiritually.Journal of Leadership of Education 6(1) 16-17.

Garet, M., Porter.,Desimori., \& Birma. 2001. What Makes Profesional Development Effective? Results from a national sample of teachers. American Education Research Journal, 38(4),915-945. 
Glickman,C. D; Gordon,P. S; \& Gordon, R, J. 2009b. The Basic Guide to Supervision and Instructional Leadership. Second edition. Allyn and Bacon: Pearson.

Gordon, S.P. 2001. The Good School. Florida Journal of Education Leadership, 1(2), 13-15.

Gordon, S.P. \& Maxey, S. 2000. How to help beginning teachers succeed. Alexandria, VA: Association for Supervision and Curriculum Development.

King, D. 2002. The Changing Shape of Leadership. Educational Leadership, 59 (8), 61-63.

Mantja, W. 2002a.Manajemen Pembinaan Profesionalisme Guru Berwawasan Pengembangan Sumber Daya Manusia: Suatu kajian Konseptual-Historik dan Empirik. Pidato Pengukuhan Guru Besar IKIP Malang: Malang.

Mantja, W. 2008b. Etnografi: Desain Penelitian Kualitatif Pendidikan dan Manajemen Pendidikan. Malang: Elang Mas.

Muhtar., Iskandar. 2009. Orientasi Supervisi Pendidikan. Jakarta: Gaung Persada Press.

Mulyasa, E. 2004. Menjadi Kepala Sekolah Profesional dalam konteks menyukseskan MBS dan KBK. Bandung: Alfabeta.

Pidarta, M. 2009. Supervisi Pendidikan Kontekstual. Jakarta: Rineka Cipta.

Pondy, L., Liwin, H. G. 2001.Organizational Symbolic.(Eds) Greenwich: JAI.

Robbins,P. S \& DeCenzo, A.D. 2004.Supervision Today, The Ultimate Guide to Front-line Management.4th edition. New Jersey: Pearson Prentice Hall.

Ruscinski, D.A. \& Hazi, H.M. 2007.Supervision as Profesional Development Compatible or Strange Bedfellows in the Policy Quest for Increased Student Achievement. Paper for Presentation at the Fall Meeting of the Council Professor of Instructional Supervision, Oct. 26-28,2007.New York,NY: Council of Professors of Instructional Supervision.

Sahertian, P.A. 2008. Kepemimpinan dan Supervisi Pendidikan. Surabaya: Usaha Nasional.

Schindler,P.L., \& Thomas,C.C. 2003. The Structure of Interpersonal Trust in the Workplace. Psyhological Reports, pp.73,563-573.

Sonhadji, A. H. 2012. Manusia, Teknologi, dan Pendidikan Menuju Peradaban Baru. Malang: UM Press.

Sukmadinata,S.N. 2006. Pengendalian Mutu Pendidikan Sekolah Menengah (Konsep, Prinsip dan Instrumen). Jakarta: Aditma.

Tosi, L.H., Rizzo,R.J \& Carrol,J.S. 2000.Managing Organizational Behavior. New York: Henry L.Tosi, John R. Rizzo,J.Carrol.

Zepeda, S.J. 2012.The Principal as Instructional Leader.A Practical Handbook ( $3^{\text {rd }}$ edt). Larchmont, NY. Eye One Education. 